811.163.41'373.43

821.163.41.08 Костић Л. https://doi.org/10.18485/sj.2019.24.1.24

ЂОРЂЕ М. ЈАНКОВИТ

Универзитет у Београду

Учитељски факултет
Оригинални научни рад

Примљен: 11. 09. 2018.

Прихваћен: 15. 01. 2019.

\title{
НЕОЛОГИЗМИ ЛАЗЕ КОСТИЋА И ЮИХОВА ТВОРБА НУЛТИМ СУФИКСОМ
}

У раду се анализирају неолошке творенице из делаิ Лазе Костића грађене нултим суфиксом, како би се установиле њихове специфичне одлике у поређењу са творбеним карактеристикама одговарајућих узуалних лексема. Истичу се терминолошки проблеми у вези с именовањем периферне лексике. Разматрају се нормативност и функције ов(акв)их Костићевих кованица, међу којима се као главне издвајају номинацијска, стилска и метричка улога. Утврђују се деривационе специфичности ових лексема: префигираност мотивних речи, сложеносуфиксална творба, творба од негираних глагола, род твореница, конкурентност - са девербативима на - $а$ и др.

Кључне речи: неологизам, девербатив, нулти суфикс, стилогеност, експресивност, нормативност.

\section{1. ПРЕДМЕТ РАДА И ГРАЪА}

1.1. Рад се бави творбеном анализом именичких твореница грађених нултим суфиксом у делима Лазе Костића. Он представља наставак и продубљење мог ранијег рада (Јанковић 2010), који је махом био посвећен формалним одликама деривата с нултим суфиксом, с нарочитим освртом на оне из Ко-

\footnotetext{
*djordje.jnkvc@gmail.com
} 
стићеве поезије. Овде ће више пажње бити посвећено њиховим функцијама и откривању разлога за ковање таквих неологизама.

Под термином твореница (дериват) подразумевам продукте свих типова грађења речи које сам анализирао (у првом реду су то изведенице - суфиксалне творенице, али и оне настале сложено-суфиксалном творбом). С друге стране, анализу сам, према семантичком критеријуму, ограничио на девербативне именице (чиме сам искључио деноминале типа кам, плам), било мушког, било женског рода. Остале критеријалне напомене у вези с грађом, језички изузетно разноврсном, дајем у т. 3.2.

Костићев језик сам одабрао не само зато што је импресивно стилоген и што обилује неологизмима твореним нултим суфиксом већ и с намером да на примеру једног експресивног језичког варијетета прикажем плодност наведеног творбеног обрасца.

1.2. Грађа. Речи које су предмет овог рада ексцерпирао сам из књига наведених у списку грађе. У тај корпус је ушла већина Костићевих песама и поема, све три његове драме и филозофски трактат Основно начело. Костићево дело из теорије естетике Основа лепоте у свету..., монографија О Јовану Јовановићу Змају..., као ни незнатни део његових песама нису прегледани. Неологизми из тих дела дефинисани и цитирани у Речнику САНУ ушли су, ипак, заједно са осталим јединицама.

За упоређивање и евентуалну допуну грађе користио сам материјал који су сакупили Марковићева (1986) и Јанковић (1969), у који улазе све Костићеве кованице. Марковићева је, осим онога што се налази у мојој грађи, прегледала још и Костићева писма, јавна и приватна, и запазила да она не садрже кованице (1986: 285, 290). Нисам укључивао неологизме из Костићевих превода, обрађене у Јанковићевом речнику.

\section{2. НЕОЛОГИЗМИ}

2.1. Терминологија. Под неологизмом ће се овде подразумевати новоскована лексема „одређеног периода које није било у претходним периодима” (Оташевић 2008: 40) и која не улази у основни лексички фонд. То су новостворене речи, на првом ступњу развоја (лексемизација), према Прћићевом погледу на развојне етапе полиморфемских лексема (2016: 89-91). Те речи нису трајне нити потпуно прихваћене од језичке заједнице и стоје наспрам устаљених (етаблираних $)^{1}$, узуалних, стабилних ${ }^{2}$ лексема. Међу таквим речима има оних

\footnotetext{
${ }^{1}$ Термин Прћићев (2016: 91), према Бауеровом established.

${ }^{2}$ Последња два термина према Драгићевић 2009a: 120. Ауторка као синонимни користи и термин реална лексема, јер полази са становишта да једном потврђене лексеме (потенцијалне
} 
које су настале из потребе за номинацијом (деноминативни неологизми, према Мухвић Димановски 2005) и оних који су створени из стилистичких, експресивних потреба (стилистички неологизми, ibid). Ту класификацију заступају и други аутори (нпр. Ковачевић 2010: 88-89) и изгледа да она делом одговара разлици коју Р. Драгићевић (2009а: 124) проналази између потенцијалних лексема и оказионализама. На то се разликовање, осим наведеног, генетског, може применити и (1) творбени критеријум (потенцијалне лексеме типично настају према продуктивним творбеним типовима, оказионализми не ${ }^{3}$ ) и (2) везаност за контекст (потенцијалне лексеме се разумеју и без контекста). Овде, дакле, узимам да оказионализми и део потенцијалних лексема ${ }^{4}$ заједно спадају у неологизме ${ }^{5}$, тим што сматрам да је термин стилистички неологизам погоднији од термина оказионализам, јер поред оказионализама може обухватати и хапаксе и индивидуализме (индивидуалне неологизме ${ }^{6}$ ), ако је између тог трога потребно уводити дистинкцију. ${ }^{7}$

У вези с појмом неологизма битно је размотрити још и критеријум времена, који се наводи као његово битно одређење. В. Мухвић Димановски, тако, сматра да статус оказионализма претходи статусу неологизма (,na pitanje koliko je vremena potrebno da bi se okazionalizam smatrao neologizmom, vrlo je teško odgovoriti”, 2005: 61). Слично на то гледају и немачки лингвисти (Штебих Голуб 2012: 420). Они заступају тезу да су оказионализми (индивидуално, ситуативно употребљене лексеме) нелексикализовани ${ }^{8}$ елементи, док су неологизми - лексикализовани оказионализми, који у ту категорију доспевају тако што испуњавају одређене услове (правилна творба, номинацијска функција..., као што је горе наведено за потенцијалне лексеме). Неки аутори (нпр. Драгићевић 2011) неологизме дефинишу само са становишта времена (,нове лексеме које се у српском језику користе последњих два-

лексеме и оказионализми) не постоје реално у језику (124). Ипак, у другом њеном раду (Драгићевић 2011: 47) индивидуална лексика, у коју улазе наведене групе речи, третира се као део лексичког система (периферијски лексички слој).

${ }^{3}$ Код Ковачевића је то „сагласност с нормативнолексичким критеријумима” (2010: 90).

${ }^{4}$ Други део би биле незабележене потенцијалне лексеме, за које постоје у систему (langue), али које (још) нису остварене у говору (parole) (Драгићевић 2009а: 122).

${ }^{5}$ Код Милановића (2012), можда с правом, нема такве дистинкције између оказионалних и потенцијалних речи. Он, анализирајући императивне сложенице код романтичара, наводи да су песници у духу вуковског језика „лако аналошки ковали потенцијалне речи”, али да продуктивност тих речи лежи у „њиховој експресивности, тј. афективности и сликовитости” (671), што значи да правилно творена реч, иако експресивна, ипак може ући у основни лексички фонд.

${ }^{6}$ Термин из руске литературе, према Оташевићу (2008: 61).

${ }^{7}$ О неуједначеној употреби тих појмова пише Р. Драгићевић (2011: 47-49), која, прихватајући праксу појединих украјинских и руских аутора, оказионализме и потенцијалне речи сврстава у индивидуализме. У овом раду се индивидуализми, ипак, узимају као подскуп неологизама.

${ }^{8}$ Прћићев термин лексемизачија, створен ради избегавања сличности с лексикализацијом, означава пак пуко стварање лексеме творбом, њен постанак. 
десетак година", стр. 49), без обзира на њихов настанак и порекло, из чега произлази да су неологизми и све речи страног порекла које су у језик ушле за то време (нпр. у савременом језику дигиталан, лаптоп), па и недавно сковане речи које су постале узуалне и које стога улазе у основни лексички фонд (нпр. испоштовати). У таквом приступу је, чини се, сема „новости” коју префиксоид нео- уноси у термин формализован, јер се занемарује узусни и семантички развој новотворенице, какав је објашњен код Прћића (1. с.) и примењен, на пример, при обради новопримљених страних речи у Речнику новијих англицизама Васићеве и др. (2011). Када је у питању време настанка одређене лексеме, Р. Драгићевић (2011: 52) инсистира на непреклапању индивидуализама, који могу бити и историзми (као јоргануша' 'она која се покрива јорганом (као знак имовног стања)', према РСАНУ), с неологизмима. С тим у супротности стоји Оташевићев поглед на неологизме као на лексеме „одређеног периода којих није било у претходним периодима” (в. горе). Они, дакле, према потоњем виђењу нису везани за време посматрања језичке појаве, као што су то историзми, већ само за време свог настанка. Неологизам је, другим речима, ако не постане узуална лексема, увек неологизам, док историзам и архаизам то одређење добијају тек на основу тренутка из ког се описују. Зато овде о речима насталим крајем XIX и почетком XX века говорим као о неологизмима ${ }^{9}$, ако је уопште пожељно речи употребљене у књижевности, а посебно у поезији, смештати на временску осу. С обзиром на то да се Костићева поезија чита, актуелизује и данас, тешко да би се иједна од његових кованица, осим оних чији су референти ефемерне појаве из човекове околине, могла назвати архаизмом или историзмом.

Изложени поглед на односе наведених термина представљам, с одговарајућим примерима, углавном из цитиране литературе, у следећој табели:

${ }^{9}$ Овај термин за такве речи користе и други истраживачи сличних лексема: Марковићева (1986), Ковачевић (2010), Милановић (2012). 


\begin{tabular}{|c|c|c|c|c|}
\hline & $\begin{array}{l}\text { Незабележене } \\
\text { лексеме }\end{array}$ & \multicolumn{2}{|c|}{$\begin{array}{l}\text { Неустаљене } \\
\text { лексеме }\end{array}$} & \multirow{4}{*}{$\begin{array}{l}\text { Устаљене } \\
\text { лексеме }\end{array}$} \\
\hline & \multicolumn{2}{|c|}{ Потенцијалне лексеме } & $\begin{array}{c}\text { Оказио- } \\
\text { нализми, } \\
\text { хапакси, } \\
\text { индивидуа- } \\
\text { лизми }\end{array}$ & \\
\hline & & \multicolumn{2}{|c|}{ Неологизми } & \\
\hline & & Номинацијски & Стилистички & \\
\hline $\begin{array}{c}\text { Језичка } \\
\text { садашњост }\end{array}$ & *врататост & $\begin{array}{c}\text { исхитрено, } \\
\text { испоштовати }\end{array}$ & $\begin{array}{l}\text { подневље, } \\
\text { крканщија }\end{array}$ & $\begin{array}{c}\text { кућа, } \\
\text { предмет, } \\
\text { трубач, } \\
\text { вредновати }{ }^{10}\end{array}$ \\
\hline $\begin{array}{c}\text { Језичка про- } \\
\text { шлост (архаиз- } \\
\text { ми, историзми) }\end{array}$ & & $\begin{array}{l}\text { осуђење, } \\
\text { покаја }{ }^{11} \\
\text { академијаш }\end{array}$ & $\begin{array}{c}\text { јоргануша, } \\
\text { безњенищуа } \\
\text { (?) }\end{array}$ & $\begin{array}{l}\text { писменица, } \\
\text { абаиија }\end{array}$ \\
\hline
\end{tabular}

На крају, термин поетизам, којим се такође могу означити лексеме што их овде анализирам, нисам узео у обзир, јер је он стилска одредница (у групу стилистичких неологизама би, на пример, могли спадати поетизми, жаргонизми и сл.), тј. означава „стилематичне и стилогене језичке јединице карактеристичне за језик појединога писца" (Ковачевић 2010: 104). Ковачевић наводи да однос између стилематичности, коју сматра формалним, језичким аспектом језичке јединице, и стилогености, коју везује за њен стилски ефекат, одговара односу између неологизма и поетизма (ibid).

2.2. Неологизми Лазе Костића. Костићеви неологизми - и не само његови него и других романтичарских песника - одавно привлаче пажњу истраживача: књижевних критичара-историчара и лингвиста. Томе је разлог изразита склоност романтичара ка лексикотворству, која одговара поетици правца у коме су стварали (Милановић 2012: 665 и даље). Костић у творењу речи можда није најплоднији међу њима (ibid), али јесте аутор неких од успелих неологизама, који су постали препознатљиви део његовог језика (као безьеница, векотрај, плетисанка...).

Један део истраживача је Костићевим твореницама приступао из нормативистичке перспективе, полазећи са становишта да оне у свему морају бити

${ }^{10}$ Лексеме предмет и трубач је Вук, како наводи у Предговору, сковао преводећи Нови завет. Вредно̀вати је у РСАНУ 1965. године означено као индивидуализам.

${ }^{11}$ Речи које су Вук, односно Б. Шулек предлагали за апстрактне појмове које данас називамо осуда и покајање. 
подобне нормираним узусима и да језичка правилност, како то изражава Белић, „нимало не смета слободноме стварању књижевника” (према Ковачевић 2010: 87). Отуд је Костићева језички „неправилна” машта за Скерлића (1960: 316) „пуштен и обезуздан парип”. На истом месту он с критиком даје речи настале у Костићевој „Песничкој врућици” (наводим оне који се тичу овог рада): гуд, жур, стер, вап, жас, тров, дуј, кив, подоб, тез, неверад, коситрес [sic], векотрај, ликомет, скотомир, непровар [sic], недровар. ${ }^{12} \mathrm{C}$ таквим је погледом на Костићев језик раскрстио М. Ковачевић, који наглашава да је свака стилема из перспективе нормативне граматике - језичка аномалија (2010: 89), а на том начелу су, додуше без његовог експлицирања, настали и неки ранији радови (Јанковић 1969; Марковић 1986).

Ставови попут наведених Скерлићевих утолико се из данашње перспективе могу узети као необјективни уколико се зна да је Лаза Костић био верни следбеник Вуковог начела и да се „углавном строго држао постојећих модела творбе” (Милановић 2012: 668). То сматра и Ковачевић (2010: 103), који на основу Костићевих суфиксалних твореница на -љив, -иште, -овит/-евит, -ље, $-a j$, каквих у изобиљу има код Вука, доказује народну провенијенцију његова језика. Сасвим, дакле, насупрот паушалним квалификацијама о „унакажавању речи” (Скерлић) стоји реч новијих истраживача ${ }^{13}$ : Костић „у погледу твораштва у језику није увек изразито индивидуална појава, већ и типичан представник поезије свога доба. [Он] ствара речи поштујући уобичајена правила, али поседује изванредну способност да осети чега у језику нема" (Марковић 1993: 290).

2.2.1. То „чега у језику нема” отвара питање статуса његових неологизама - јесу ли они номинацијски или стилистички? Именују ли се њима неименовани појмови или се онеобичавају већ именовани? Према мојој грађи, у Костићевој поезији има и једних и других случајева, што одговара стању међу императивним сложеницама (Милановић 2012: 668). Други пак аутори о томе говоре недоследно. Ковачевић најпре наводи да су „стилистички разлози били једини који су Костићу наметали употребу неологизама у функцији поетизама" (2010: 106). Марковићева, разматрајући неологизме ропка, несућенка, двоженица, брежан, ружик, злост, тврди да су „Костићеве новостворене речи већином синонимичне са постојећом лексиком” (1993: 289), али да „служе за

${ }^{12}$ Неких од њих нема у мојој грађи, а лексеме коситрес и непровар Скерлић чак погрешно цитира (код Костића је косотрес и непровир)! И М. Радовић Тешић (према Драгићевић 2011: 53), узгред, погрешно наводи Фелишћани ум. Костићевог Филишћани (= Филистејци). Сви ти примери, који кушају језичко осећање и књижевника и лингвиста, показују да творбене игре Костићеве језички материјал протежу до граница растегљивости, али унутар тих граница, сматрам, ипак остају.

${ }^{13}$ Изузетак од тога представља рад Чаркић 1993. За тог су аутора Костићеве творенице, попут тако прозирног врис, „одступање од норме” (301). 
изражавање афективности, за појачавање или ублажавање значења не само садржајем и формом него и звучним асоцијацијама које као такве изазивају" (1993: 290). Другде у цитираним радовима они ипак стављају акценат на семантичке новине које уносе Костићеви неологизми. Марковићева ће рећи да, „осећајући могуће празнине у постојећим морфолошким и лексичким системима, Костић уводи [...] иновације” (Марковић 1993: 288), да се „не може пренебрећи велика семантичка важност Костићевих кованица" (290) и да такве речи „иако синонимне, на друкчији начин од конкурентних стандардних представљају именовани појам" (Ковачевић 2010: 102), јер за тај део речи појмова „рјечник књижевног (стандардног) језика не нуди лексикографско рјешење” - а они су „тако драги и потребни Лази Костићу” (ibid: 99-100). Потоњи аутор на још три места (стр. 100-101) говори о „потреби именовања”, „недостајању адекватног израза" и сл., да би на крају ипак успоставио горе наведену дихотомију између речи створених ради именовања и „'алтернативних' израза”, који су „увијек стилски маркирани” (101). Важно је напоменути да та подела не одговара сасвим подели на номинацијске и стилистичке неологизме, јер у поезији и ови први могу имати (и најчешће имају) експресивну функцију.

Тешко је понекад разграничити „експресивно” значење (које би се могло довести у везу с напред наведеном (а) афективношћу, (б) појачаним и ублаженим значењем и (в) звучним асоцијацијама, односно, у лексиколошким терминима - с конотаиијом речи) од новог, неименованог значења. Ковачевић пак иде даље од конотације и за стилистичке неологизме каже: они „дијеле са конкурентним стандарднојезичким лексемама исто денотативно значење, али се од њих разликују по свом специфичном сигнификативном значењу (2010: 102, подвлачење моје). То убедљиво објашњава примерима запитљив, изобилник, умованка, векотрај, кажичас, пустородан, који у поређењу са својим немаркираним синонимима имају или наглашене одређене семе (радознао - запитљив) или су просто сликовитије (кажичас - часовник). ${ }^{14}$ Нејасан је у том смислу коментар М. Чаркића (1993: 301), који сматра да се „нови семантички потенцијал може изразити у виду додатне значењске нијансе" ( је ли та нијанса ново значење?), а посебно је неуверљиво његово тумачење неологизма врис - „дуготрајно вриштање, врисак који се истиче силином и дужином трајања".

У истраживањима се пак и номинацијска и експресивна улога неологизама често умањују до те мере да се они своде на лексеме творене искључиво из метричких разлога. Марковићева примећује да су неологизми најфреквентнији у стиху, „што показује да је велики број кованица сачињен да би формом и

${ }^{14}$ Према терминологији коју износи Р. Драгићевић (2007: 59-60), пре би се рекло да синонимски парови радознао - запитљив и сл. имају исти сигнификат (појам о особини), да деле критеријска обележја, а да им се разликују денотати. 
фонетским склопом били задовољени закони структуре стиха (рима, версификација ${ }^{15}$, гласовна хармонија и сл.)" (1993: 290), док им Чаркић (1993) приступа тако што их обрађује искључиво према фонијским фигурама, на основу тога да ли у поређењу са стандардном синонимском лексемом имају више или мање фонема. Творенице глед, жас и свит, тако, одређује као „скраћене”, а свит ставља у исту раван са простом аферезом тииа $<$ птица (298)! Ковачевић је у томе доста прецизнији: он, иако подробно анализира такве „фонолошке фигуре" (2010: 90-99) и, парафразирајући Д. Витошевића, закључује да Костића „стих и његов језички 'живац' нагоне да речи [вик, врис, јав, жест, крас, шет, мор, снебив, опорав, узбуд, омиљ, омраз] скраћује" (103-104), признаје да је „неријетко управо нијансирање значења основни разлог творбе конкурентног стилематичног поетизма", што поткрепљује низом примера (погледак, гризутак, жељукати, натпркосити, другаричити, подрамак, скрнавка, гонивек, зимогроз, озломражен, плетисанка, косотрес, брадоглад, укључујући и све на не-: небратим, недосип, недоскок, недочек, незазор, неисказ...) (106).

Костићеви неологизми претежно означавају апстрактне појмове. То закључује и О. Ристић на основу грађе из других романтичарских песника и наводи да се ту истичу именице са значењем осећања, стања и особина (Милановић 2012: 668). Та апстрактна значења се врло лако могу преливати из једног у друго, па и развијати полисемантичке структуре: „Понекад песник намерно оставља да кованица зрачи полисемијом, нарочито код једносложних речи и сложеница, када творбени елементи нису довољно очувани, када узима вишезначан суфикс или када добија хомониме ${ }^{16 ”}$ (Марковић 1993: 290). Марковићева чак установљује Костићев ,принцип скривањ $а$, под којим се подразумева то да се језичком формом скрива значење, не би ли се тако отвориле широке могућности за слободно тумачење" (1993: 291, подвлачења моја). Императивне сложенице наших романтичара, с друге стране, како је утврдила Д. Ратковић, немају полисемантичку структуру (Милановић 2012: 671).

2.2.2. Други разлози за ковање неологизама. Досад сам разматрао три у литератури забележена фактора која су утицала на Костићево творење кованица: (1) експресивност (стилогеност), (2) именовање нових појмова, (3) метрика (усклађивање броја слогова у стиху и успостављање риме).

${ }^{15}$ УП. с тим скраћивањем тако давни критички осврт Вука Караџића на поезију Лукијана Мушицког: „Шта ми маримо за његове слогове и за стихове, то је његова брига; за то тражи бесмртну славу: а кад би ласно било стихове писати, какву би онда поета имао част?” (Ивић 2005:130). Ту ригидну Вукову тезу оповргава П. Ивић (ibid), дајући као контрааргументе примере с фонијским упрошћавањем из народних говора и народне поезије.

${ }^{16}$ Осим што полисемију третира заједно с хомонимијом, ауторка, мислим, греши и кад наводи да девербали гас, мраз и деадјективне именице безазлен, драгоиен могу изазвати колебање у разумевању (1993: 289). На страну што граматички и семантички контекст готово потпуно разрешава такву дилему (в. нпр. примере из следеће тачке), значења хомонима су најчешће из различитих домена, за разлику од оних насталих полисемијом, која могу бити веома блиска. 
Уз (1) треба додати да се стилски потенцијал неологизама очитује у њиховој сликовитости, свежини и, у случају сложеница, у „неочекиваности и оригиналности везе" међу саставницама (Милановић 2012: 670). Један део те сликовитости потиче од пресликавања представа које изазивају творенице настале по одређеном творбеном моделу. Тако лексема изведена нултим суфиксом трес $c^{17}$, која значи готово исто што и тресеље, са нултим суфиксом преузима и асоцијације које изазивају сродне лексеме интензивног значења: nотрес, земьотрес, а можда чак и њихове семе интензитета. Ова појава је, наравно, у вези са немаркираношћу суфикса -(j)e/-юе, којим се творе глаголске именице (в. ниже у овој тачки).

Употреба поетских неологизама, као експресивних лексема, још је везана и за смисао дёла у којем се појављују, па и за (језичке) одлике књижевног правца. Ово друго би се вероватно могло доказати упоредним истраживањем неологизама код писаца који су стварали у различитим стиловима или припадали различитим правцима, а повода за ту претпоставку даје опозиција између доминантних поетизама класицистичке и романтичарске књижевности, коју помиње Милановић (2012: 671). С друге стране, неологизми могу бити у директној вези и са семантичком структуром песме. В. Јанковић (1969) то показује на примеру „Самсона и Делиле”, где у певањима која описују разузданост страсти Костић употребљава и разуздан песнички израз (чак 47 неологизама!), док тамо где то смисао суспреже (IV певање) нема ниједне кованице.

Као четврти разлог за творбу неологизама нултим суфиксом може се издвојити један стриктно морфолошки. Наиме, девербативне именице на могу се регуларно градити и од свршених и од несвршених глагола, за разлику од оних на -(j)e/-ње, па су стога облици прекип, опорав, непровир, загрл прихватљивији од хипотетичких *прекипље́ъе, *опоравље́ъе, *(не)провире́ъе, *загрље́ғее, мада неке од њих имају конкурентске форме с другим суфиксима (загрљај, опоравак). Поред тога, изведенице са будући да већином не изазивају умекшавање финалног сугласника окрњене глаголске основе. То и објашњава откуд чак $44 \%$ Костићевих девербатива са нултим суфиксом потиче од глагола VI Стевановићеве врсте (Јанковић 2010: 21), који у форми на -еље јотују финални сугласник основе: нпр. жуд, гроз, крас према жуђење, грожење, крашење с нагомиланим палаталима. Глаголи из наведене групе ни иначе нису склони да граде именице на -(j)e/-ње (Клајн 1998: 153). Ипак, на примеру кип, који чак ступа у однос хомонимије са лексемом кип 'статуа' и чије се значење може изразити и типичном глаголском именицом кипљење, видимо да семантички и стилистички фактори односе превагу над формалним.

${ }^{17}$ „Стреса се слика у тресу све јачем” (Ђурђеви ступови). 
На крају, ваља приметити да творенице с нултим суфиксом у Костићевој поезији ступају у разне синтагматске односе. На првом месту су ту просте, али врло тесне (а) конјункције антонима̂ притег и одбој, одмах и домах ${ }^{18}$, за њима (б) асиндетске конјункције, попут „[отераће нас] отежући свечану проповед [...] | у недоглед, у пусти недочек” (Пера Сегединаи, III чин), „Поклонише се старци у повлад, | у један клим, у један брадоглад" (Самсон и Делила), те (в) спојеви творенице и мотивног глагола у хијерархијском односу предиката и прилошке одредбе (начинске/месне), која је често у инструменталу: шкрипну врата на дворани | иумом, икрипетом (Дим); трепетљике звеком звече (Еj, ропски свете); стреса се слика у тресу све јачем (Ђурђеви ступови); на исток $^{19}$ источиће се (Пера Сегединаи) и сл. ${ }^{20}$ Последњој појави је сродна веза из стиха: ито тако мили миловања час (Максим Црнојевић, IV чин), која два стиха ниже крије успешан каламбур, сачињен уз помоћ творенице с нултим суфиксом Па ко је криваи часомилу том? ${ }^{21}$ У синтагматске везе у које ступају ови девербативи спада и грађење предлошко-падежних конструкција с месним, временским, количинским, а посебно начинским/околносним значењем $(y / \mu a$ + акузатив/локатив): мора (ићи) у послед (Пера Сегединаи, II чин); [пропали су ми снови] на угод живу пакости жуте (Santa Maria della Salute); [осмејак] што с' из отих дивских груди у надиму тешком буди (Самсон и Делила); те већ поменути пример Поклонише се старии у повлад, | у један клим, у један брадоглад (Самсон и Делила).

Костићеви неологизми на - $~$ често се појављују у истакнутој - финалној позицији у стиховима, чак и у узастопним:

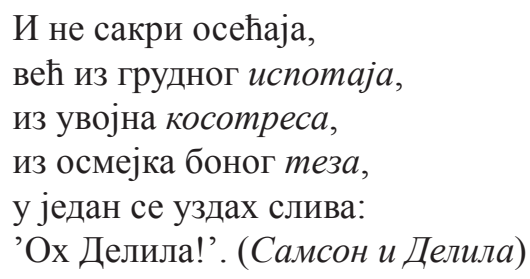

И не сакри осећаја, већ из грудног испотаја, из увојна косотреса, из осмејка боног теза, у један се уздах слива: 'Ох Делила!'. (Самсон и Делила)

${ }^{18}$ „У ње [симетрије] влада исто начело што у динамици удешава притег и одбој, атракцију и репулсију, центрипеталну и центрифугалну снагу, што одређује размере у клаћењу клатна" (Основно начело, стр. 61); „Аристотел је дакле баш управо својом жестоком навалом на основно начело Емпедоклово и Хераклитово у одмаху и домаху свога духа" (Основно начело, стр. 55).

${ }^{19}$ Ова лексема синхронијски није мотивисана, па Костићев каламбур залази у етимологију.

${ }^{20}$ Уп. с тим таутолошке објекте из народне књижевности град градила, везак везе...

${ }^{21}$ УП. и занимљиву игру творбеним поступцима [Бог се оправљао] у један лик да сложи, један лог, [створења сву дивоту]. Лексему лог с уобичајеним значењем 'легало, лога; лежиште' Костић мотивише етимолошки сродним глаголом ложити 'полагати' (лог је 'оно у шта се нешто ложи = полаже'). С друге стране, за животињску логу употребљава твореницу лег (липа беше славујима лег)! 
а ступају и у формални парадигматски однос - римотворност:

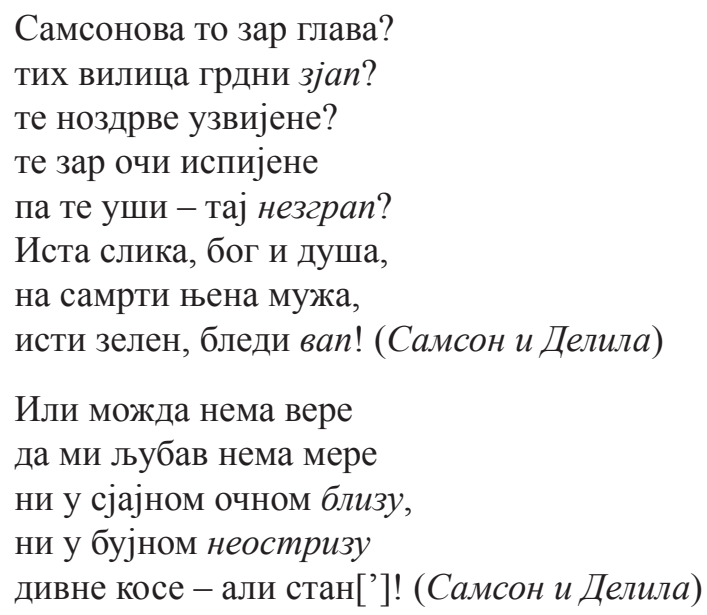

2.2.3. Неологизми или архаизми? Један део грађе који би испунио критеријуме из т. 1 - није ушао у даљу анализу. Реч је о лексемама које су у Костићево време, по свој прилици, биле већ у употреби или из ње излазиле. Зато оне нису сврстане у неологизме. Њих је, дакле, Л. Костић вероватно већ познавао/употребљавао. То потврђују речници (РСАНУ, РМС), који наводе примере употребе из времена старијег од краја XIX и почетка XX века. Ради се о речима запон, сапон, смок, крок 'корак', устук, разбор, подвоз, оглед 'двобој', разбој, сет 'сета', покор 'покора', свет 'савет', одмах, обрт, разблуд, чанколиз, благочаст/-чест, жест, обавест, као и о мање маркираним лексемама: сев, миг, рик, иик, мекет, јек.

\section{3. ДЕРИВАТИ С НУЛТИМ СУФИКСОМ У СРПСКОМ ЈЕЗИКУ И КОД КОСТИЋА}

3.1. Творенице с нултим суфиксом веома су сложене за анализу, на више језичких планова. Осим што је постојање тог суфикса, као варијанте нултог језичког знака уопште, по себи парадоксално (да се ничим изражава нешто!), због чега одавно заокупља пажњу истраживача (в. Јанковић 2010: 3-5), он носи више фонолошких и морфолошких посебности (ibid, 6-13):

1. Долази на редуковане глаголске основе (осим код глагола I и III врсте) (поглед-ф : погледа-).

2. Њиме се творе, атипично, и деноминали: кам, плам од камен, пламен.

3. Постоји у две варијанте: - ${ }_{1}$ (који твори именице мушког рода типа позив) и - ${ }_{2}$ (који твори именице женског рода типа проповед). ${ }^{22}$

${ }^{22}$ Неки аутори су овде формално строжи, па и монофонемске форманте попут - $a,-e,-o$ (напомен- $a$, jap-e, Jов-о) третирају као спој нултог творбеног афикса и наставачке морфеме (- 
4. Изазива бројне морфофонолошке алтернације:

a) Сугласничке: палатализација (плакати-плач), депалатализација (скочити-скок, бежати-бег, послушати-послух), десибиларизација (дисати-дах), јотовање (водити-вођ),

b) Вокалске: апофонија (дотећи-доток, бити-бој, покритипокров, смрдети-смрад, грмети-гром, примити-пријем, $у$ брисати-убрус), с могућим двојаким и тројаким резултатима: избор-одабир, извор-увир, слој-слив, исток-истек; продор-додир-облакодер...,

c) Непостојано а: зајам, камаљ, врисак, прасак; секундарно по-

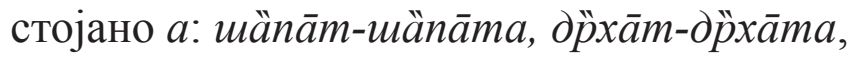

d) Појава секундарних сугласника: иити-щав, лити-лој,

е) Обезвучавање финалног консонанта: бризак, звизак (< звизаг < звизг, према *звиз(г)нути).

Нулти суфикс представља и методолошки проблем, с обзиром на то да би се његови деривати могли сврстати у примере за конверзију (јер није изражен формалним творбени материјалом, већ има само морфолошке преоблике), за регресивну деривацију (аналогни са раздрешити $\rightarrow$ дрешити) или за продукте аналогије (договорити $\rightarrow$ договор, али * разговорити $\rightarrow$ разговор). Такође, у неким примерима је проблематичан и смер деривације: зној : знојити, стид : стидети се, брус : брусити и сл. ${ }^{23}$

3.2. Наведене творбене особине деривата с нултим суфиксом начелно важе и за неологизме Лазе Костића. Међу њима су најбројнији примери творени чистом суфиксацијом, што потврђују и друга истраживања (Марковић 1993: 290), а међу њима је незнатно више префигираних (докон, домах...) од непрефигираних глагола (бран, брид...) - приближно 55\% : 45\%. Упадљиво мањи број њих настао је сложено-суфиксалном творбом, са најчешћим односом саставница субјекат - предикат (недромир, часомил...) и предикат - објекат (брадоглад, колотер...). ${ }^{24}$ Има нешто и оних насталих префиксално-суфиксалном творбом, ако прихватимо такву деривацију неколико речи на не- (недоглед, недозив...). Те се творенице - упркос тврдњама Марковићеве (1986: 288) у

и сл.). Бабић тај приступ разматра, па од њега одустаје (1981: 7-9), закључујући да за писање нуле има разлога само онде где заиста нема материјалног израза да именује граматички знак. Р. Маројевић (2012) се пак доследно држи наведеног формалног принципа.

23 Лексема глум, на пример, коју налазимо код Костића и коју етимолошки речници (Скоков и Глухаков, s. v. gluma) одређују као корен од којег је настао деноминал глумити, за савременог говорника је пре, као и глума, мотивисана реч, творена од глагола глумити.

${ }^{24}$ Милановић (2012: 670) сматра да су императивне сложенице „можда најбољи доказ да је и реченица подложна лексикализацији”, јер се у њима сложенице „приближавају синтагмама и реченицама". 
вези с лексемама недочек, неисказ - не могу третирати као префиксалне, јер према себи углавном немају мотивне речи (недосип : не $+*$ досип) и посебно зато што се парафразирају мотивним глаголом (недосип 'оно у шта се не може досути'), а не именицом. Споран је и статус форманта не-, који, према Клајновом (2002) приступу, представља префикс, док га други аутори (нпр. Маројевић 2005: 753) третирају као основу (речцу).

У Костићевој поезији има и твореница женског рода с нултим суфиксом (благочаст, благочест, враж, жест, жуд, зимогроз, намен, наслад, разблуд, слад), које се ни по значењу ни по основном облику не разликују од својих пандана мушког рода. Пажњу привлаче парови жуд м : жуд ж ${ }^{25}$ и слад м : слад ж ${ }^{26}$, оба забележена код Костића, као и маскулинум замисао ${ }^{27}$. У неким случајевима контекст није откривао род именице ${ }^{28}$.

Слично томе, стихови „Што ћу од миља, од муке љуте” (Santa Maria della Salute) и „где је врело сваког миља” (Међу звездама) не показују је ли у питању именица миље или миљ, а то важи и за именице потвор/noтвора, из стиха „Вештака вечног творилачка свест [...] | и своју слику створи, човека [...] | И по томе не беше потвора" (О Шекспировој тристагодишњиции).

Неке лексеме немају синхронијске везе са глаголом од којег би могле бити изведене (или тај глагол уопште не постоји). Прикус и презор су вероватно настали по аналогији са девербативима привид, превид (речници не бележе *прикусити, *nрезорити, а презрети се значењски одвојило од зрети 'гледати'). Према усмок нема *усмочити, али постоји аналошка веза са смок и умочити. Докон се може изводити од дочети, доконити, доконати, евентуално и од докончати, мада се ниједан од тих глагола, осим последњег, не користи. Жас се, исто тако, формално може изводити од архаичног жаснути, али је очитија веза с нескраћеним ужас (< ужаснути (се)). Пирук и сикут су од пиркати, сиктати, али се од њих не могу изводити (системски облици би били *пирак и * сикат, као врисак и шапат); на њихов облик утицао је и горук од горукати.

Мада неологизми степен 'степеник' и шар 'шаренило' (као и чести поетизам кам 'камен') очито нису девербативи, примери омраз и гроз могли би се тумачити и девербативно, ако се не узме да је у оба случаја у питању обична редукција основе, будући да суфикс не уноси ново значење. Такву

${ }^{25}$ „[Нуди ми] сву своју душу, све своје жуде” (Santa Maria della Salute), али: „напитљиву намирити му жуд” (Максим Црнојевић, III чин).

${ }^{26}$ „[Нуди ми] јаде па сладе, чемер па мед” (Santa Maria della Salute), али: „и прекипе живота прва слад” (Ox, жао ми те је). III чин).

${ }^{27}$ „Грех тешки кају лаком кичицом, | замисао лак у тешки режу кам” (Пера Сегединац,

${ }^{28}$ На пример стих „причујмо му жес”” (Максим Црнојевић, IV чин), али иначе: „[Ђаво] улови ми гујном замком | обезумну моју жест” (Самсон и Делила). 
дилему остављају и лексеме близ (,[љубав ми нема мере] ни у сјајном очном близу”), испотај („И не сакри осећаја, већ из грудног испотаја [...] | у један се уздах слива: | 'Ох Делила!'”) и незграп (,[Зар су то] те уши - тај незграп?”), сви из Самсона и Делиле.

4. Из свега излази да су анализирани неологизми Лазе Костића бременити улогама и упошљени да изразе многе језичке нијансе: различиту денотацију, конотацију, да изазову асоцијацију на чулни осећај, доживљај, па и да полисемичношћу оставе места различитим интерпретацијама. Због својих специфичних одлика, као што су бројивост, формална краткоћа и др., којима се одвајају од твореница с конкурентним суфиксима, они су погодни метру и рими, а у неким случајевима се граде доста лакше него девербативи на -je. Утврђено је да међусобно ступају у различите синтагматске и парадигматске односе (синдетски и асиндетски саставни однос, таутолошка конструкција с предикатом, предлошко-падежна конструкција с околносним значењем; римотворност) и да је њихова употреба уско повезана са поетиком епохе и књижевног дела.

С творбене стране, Костићеви неологизми разнолики су по начину грађења (суфиксација, сложено-суфиксална и префиксално-суфиксална творба), по префигираности мотивног глагола, по роду и родној флуидности. Њиховој семантичкој неједнозначности потпору даје граматичка, творбена амбиваленција, која се у појединим случајевима види у (намерно створеним?) потенцијалним хомоформским паровима (ген. јд. миљь $а$, ном./ген. јд. потвора), а у другима - у аналошким образовањима, попут прикус, усмок, сикут, која се служе формалним и семантичким садржајима различитих лексичких извора како би неологизам што успешније прецизирао, нијансирао или онеобичио зацртани појам.

\section{ГРАЂА}

Костић 1961: L. Kostić, Osnovno načelo, Beograd: Kultura.

Костић 1962а: Л. Костић, Песме. Прозни списи (Одабрана дела I), Нови Сад - Београд: Матица српска - Српска књижевна задруга.

Костић 1962б: Л. Костић, Трагедије. О позоришту (Одабрана дела II), Нови Сад - Београд: Матица српска - Српска књижевна задруга.

Костић 1964: Л. Костић, Максим Црнојевић; Пера Сегединац, Београд: Савремена администрација.

Костић 1987: Л. Костић, Драме, Београд: Нолит.

Костић 2009: Л. Костић, Песме, Антологија српске књижевности, на сајту: www.ask.rs 


\section{ЛИТЕРАТУРА}

Бабић 1981: S. Babić, Tvorba imenica nultim sufiksima, Bilten Zavoda za lingvistiku, 4, 4-52.

Васић и др. 2011: V. Vasić, T. Prćić, T. Nejgebauer, Du yu speak anglosrpski? Rečnik novijih anglicizama, Novi Sad: Zmaj.

Драгићевић 2007: Р. Драгићевић, Лексикологија српског језика, Београд: Завод за уџбенике.

Драгићевић 2009a: Р. Драгићевић, Потенцијалне речи у српском језику, НССУВД, 38/3, 119-126.

Драгићевић 2009б: Р. Драгићевић, Утицај полисемије на творбу речи, Књижевност и језик, LVI/1-2, 147-153.

Драгићевић 2011: Р. Драгићевић, Лексика квалификована као индивидуална у српским дескриптивним речницима, $y:$ В. Ружић, С. Павловић (ур.), Лексикологија, ономастика, синтакса, Нови Сад: Филозофски факултет, 47-57.

Ивић 2005: M. Ivić, O rečima, Beograd: Biblioteka XX vek.

Јанковић 1969: В. Јанковић, Поетска функција кованица Лазе Костића, Зборник историје кьижевности, 7, 1-81.

Јанковић 2010: Ђ. Јанковић, Творбено-семантичка анализа изведенииа на нулти суфикс (с освртом на грађу из поезије Лазе Костића (необјављени семинарски рад, Филолошки факултет у Београду).

Клајн 1998: И. Клајн, Граматички и лексикографски статус глаголских именица од несвршених глагола, НССУВД, 27/2, 149-157.

Клајн 2002: И. Клајн, Творба речи у савременом српском језику I. Слагање и префиксачија, Београд - Нови Сад: Завод за уџбенике и наставна средства - Институт за српски језик САНУ - Матица српска.

Клајн 2003: И. Клајн, Творба речи у савременом српском језику II. Суфиксаиија и конверзија, Београд - Нови Сад: Завод за уџбенике и наставна средства - Институт за српски језик САНУ - Матица српска.

Ковачевић 2010: М. Ковачевић, О поетизмима Лазе Костића, y: Ј. Зивлак (ур.). Поезија и естетика Лазе Костића, Нови Сад: Друштво књижевника Војводине, 85-108.

Марковић 1986: Д. Марковић, Лингвистичка анализа кованица Лазе Костића, ППЈ, 22, 145-161. 
Марковић 1993: Д. Марковић, Кованице Лазе Костића и дискурс, НССВД, 21/1. 285-294.

Маројевић 2005: Р. Маројевић, Творба речи у савременом српском језику Ивана Клајна (1), Српски језик, 10/1-2, 685-779.

Маројевић 2012: Р. Маројевић, Српски и словенски нулти суфикс, у: Р. Драгићевић (ур.), Творба речи и њени ресурси у словенским језищима, Београд: Филолошки факултет, 637-651.

Милановић 2012: А. Милановић, Стилски аспекти творбе тзв. императивних сложеница у српској романтичаркој поезији, $y$ : Р. Драгићевић (ур.), Творба речи и њени ресурси у словенским језицима, Београд: Филолошки факултет, 663-673.

Мухвић Димановски 2005: V. Muhvić-Dimanovski, Neologizmi: problemi teorije i primjene, Zagreb: Filozofski fakultet, Zavod za lingvistiku.

Оташевић 2008: Ђ. Оташевић, Нове речи и значењ а у српском језику, Београд: Алма.

Прћић 2016: T. Prćić, Semantika i pragmatika reči, Novi Sad: Filozofski fakultet.

PMC: Речник српскохрватскога књижевног језика I-VI, Нови Сад: Матица српска.

РСАНУ: Речник српскохрватског књижевног и народног језика I-XIX, Београд: Српска академија наука и уметности.

Скерлић 1967: Ј. Скерлић, Историја новије српске къижевности, Београд: Просвета.

Чаркић 1993: М. Чаркић, Именичке метаплазме у поезији Лазе Костића, НССУВД, 21/1, 295-302.

Штебих Голуб 2012: В. Štebih Golub, Okazionalizmi u hrvatskome publicističkom stilu, y: Р. Драгићевић (ур.), Творба речи и њени ресурси у словенским језицима, Београд: Филолошки факултет, 419-435.

\section{LAZA KOSTIĆ'S NEOLOGISMS AND THEIR DERIVATION WITH NULL SUFFIX}

\section{Summary}

The paper analyzes neological derivatives in works of Laza Kostić formed with null suffix, in order to discover their specific features compared to those of respective established lexemes. Terminological problems related to the nomination of peripheral lexicon 
are highlighted. The normativity and functions of Kostić's coinages are considered, among which the nominative, stylistic and metric roles are distinguished as the main ones. The derivative specifics of these lexemes are determined: the prefixation of motive words, the compound-suffixal formation, the formation of negated verbs, the gender of the derivatives, the competition with deverbatives with suffix $-a$ etc.

Keywords: neologism, deverbative, null suffix, stylogenity, expressivity, normativity. 